\title{
Development of Bacterial Spot, Incited by Xanthomonas cucurbitae, in Pumpkin Fields
}

\author{
Abbasali Ravanlou and Mohammad Babadoost ${ }^{1}$ \\ Department of Crop Sciences, University of Illinois, Urbana, IL 61801
}

Additional index words. cucurbits, Cucurbita pepo, bacterial leaf spot, pathogen identification, disease etiology

\begin{abstract}
This study was conducted to assess occurrence of bacterial spot, incited by Xanthomonas cucurbitae, on pumpkin leaves and fruit. Development of the disease was monitored in 9, 14, and 15 commercial pumpkin fields in 2009, 2010, and 2011, respectively, in Illinois. Bacterial spot was observed from 4-leaf growth stage until the green leaf tissue was unavailable. Three types of lesions were observed on leaves, which were described as Type I, Type II, and Type III lesions. Type I lesions were small (1 mm), angular, brown necrotic spots, and numerous on each leaf. Type II lesions were angular, beige in the center with brown halo, numerous on each leaf, and measured 1 to $4 \mathrm{~mm}$. Type III lesions were angular, translucent spots with a narrow chlorotic halo, only a few spots on each leaf, and measured 4 to $8 \mathrm{~mm}$. Incidence and severity of bacterial spot on leaves were the greatest when fruit began to turn to orange. Bacterial lesions were observed on fruit from 1 week after fruit set until harvest. Lesions on fruit were circular, water-soaked, sunken, with beige centers and chlorotic halo, and measured 1 to $3 \mathrm{~mm}$. Occurrence of bacterial spot on fruit was assessed in 17, 50, and 65 commercial pumpkin fields in 2009, 2010, and 2011, respectively. The disease on fruit was observed in $100 \%$, $80 \%$, and $88 \%$ of the fields surveyed in 2009,2010 , and 2011 , respectively. The incidence of fruit with bacterial spot in all fields surveyed was $46 \%, 35 \%$, and $24 \%$ in 2009,2010 , and 2011, respectively.
\end{abstract}

Bacterial spot of pumpkin, incited by $X$. cucurbitae (ex Bryan) Vauterin et al. (1995) [syn. Xanthomonas campestris (Pammel) Dowson pv. cucurbitae (Bryan) Dye], has become one of the most important diseases of pumpkin [Cucurbita pepo L. and Cucurbita moschata (Duchesne) Duchesne ex Poir] in Illinois and some other pumpkin-growing areas in the United States (Babadoost et al., 2012; Babadoost and Ravanlou, 2012; Babadoost and Zitter, 2009). This disease was first reported as bacterial leaf spot on 'Hubbard' squash in New York in 1926 (Bryan, 1930). Subsequently, the disease was identified in other cucurbit-growing areas in Asia, Australia, Europe, and North America on cucumber, pumpkin, squash, and watermelon (Bineeta et al., 1999; Dutta et al., 2013; Lamichhane et al., 2010; Pruvost et al., 2008; Pruvost et al., 2009; Williams and Zitter, 1996).

Xanthomonas cucurbitae infects leaves and fruit of cucurbit crops (Babadoost and Ravanlou, 2012; Saddler and Bradbury, 2005; Williams and Zitter, 1996). Symptoms reported on leaves of gourd, pumpkin, and squash are small (2-4 mm), chlorotic to beige spots (Babadoost and Zitter, 2009; Williams

Received for publication 26 Dec. 2014. Accepted for publication 24 Mar. 2015.

This research was supported in part by funds from NCR-IPMC Grants (USDA-NIFA Project No. 2007-51120-18445) and NCR-SARE Grants (Project No. GNC10-144).

${ }^{1}$ To whom reprint requests should be addressed; e-mail babadoos@illinois.edu. were: 1) monitor development of bacterial spot on pumpkin leaves and fruit in commercial fields during the growing season; 2) define symptoms of the disease on leaves and fruit of various pumpkin cultivars; and 3) assess incidence of pumpkin fruit with bacterial spot at harvest in commercial fields.

\section{Materials and Methods}

Disease development on leaf and fruit. In 2009, 2010, and 2011, nine, 14, and 15 commercial pumpkin fields, respectively (Fig. 1), were selected to monitor the development of bacterial spot on leaves and fruit. Fields ranged in size from 2 to 16 ha. All fields were visited every 2 to 3 weeks, beginning 4 weeks from seed sowing until about 3 weeks before harvesting fruit. In each field, 12 locations, with about equal distance from each other on an M-shaped path, were selected and flagged. In each location, 20 leaves on five plants and five fruit were randomly selected and examined for development of bacterial spots. Incidence of bacterial spot in each field was determined as percentage of symptomatic leaves and fruit. Severity of bacterial spot on leaves and fruit was assessed by naked eyes and it was percent leaf or fruit area with bacterial lesions. Severity of the disease in each field was calculated by adding percent areas of leaves or fruit with bacterial spots and then dividing by number of leaves or fruit examined. Characteristics of the lesions including shape, size, and color on leaves and fruit were recorded. In each visit to the field, symptomatic leaves and fruit were collected, transported in a cooler to the laboratory, stored in a cold room $\left(4{ }^{\circ} \mathrm{C}\right)$, and processed for isolation of associated bacteria within $3 \mathrm{~d}$ from collection.

Occurrence of bacterial spot on fruit was assessed in 17, 50, and 65 commercial pumpkin fields in 2009, 2010, and 2011, respectively (Fig. 2). All monitored fields for development of bacterial spot on leaves and fruit during 2009-11 were included in these surveys. The fields were surveyed within 3 weeks before harvest. In each field, 12 locations on an M-shaped path were selected and, in each location, five fruit were randomly selected and examined for the presence of bacterial spot. Symptomatic fruit were collected and the associated bacteria were isolated in the laboratory.

Isolation of bacteria. Surface of leaves and fruit were disinfested by gentle rubbing with blotters soaked in $99 \%$ ethanol. Then, the area with lesions was excised using a sterile scalpel (pieces 2-4 $\mathrm{mm}$ in diameter) in a biological safety hood. Each leaf or fruit piece with a single lesion was inserted into a $1.5-\mathrm{mL}$ microcentrifuge tube containing $1 \mathrm{~mL}$ of sterilized distilled water (SDW). The tube was shaken using a shaker (Thermolyne Maxi Mix ${ }^{\circledR} \mathrm{II}$, Barnstead International, WI) for $30 \mathrm{~s}$, and then a loopful of the suspension was streaked onto the kasugamycin-cephalexin agar $(\mathrm{KC})$ medium in $100-\mathrm{mm}$ petri plates, 

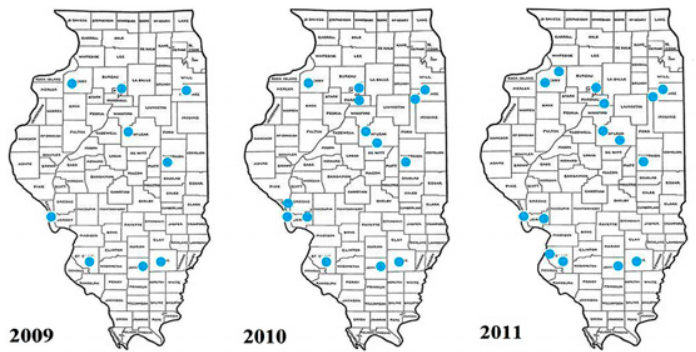

Fig. 1. Locations of monitored pumpkin fields (blue dots) in Illinois, where development of bacterial spot (Xanthomonas cucurbitae) on leaves and fruit was studied during 2009-11.
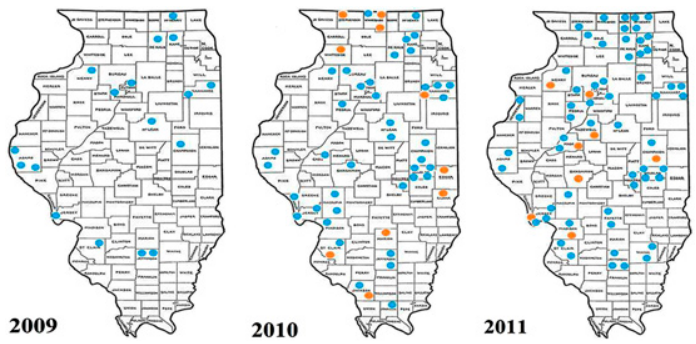

Fig. 2. Locations of commercial pumpkin fields in Illinois that were surveyed for occurrence of bacterial spot (Xanthomonas cucurbitae) on fruit during 2009-11. Blue dots indicate fields with infected fruit and red dots show fields without symptomatic fruit.
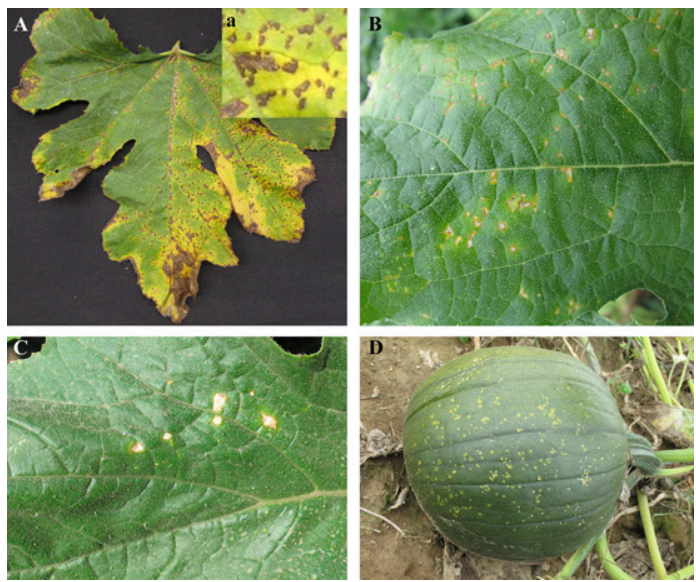

Fig. 3. Symptoms incited by Xanthomonas cucurbitae on pumpkins. (A) Type I lesions on a leaf of cultivar Magic Lantern [(a) a close up of the brown necrotic lesions on the upper surface of a leaf]; (B) Type II lesions on a leaf of cultivar Autumn King; (C) Type III lesions on a leaf of cultivar Spartan; and (D) water-soaked lesions on an unripen fruit of cultivar Magic Lantern.

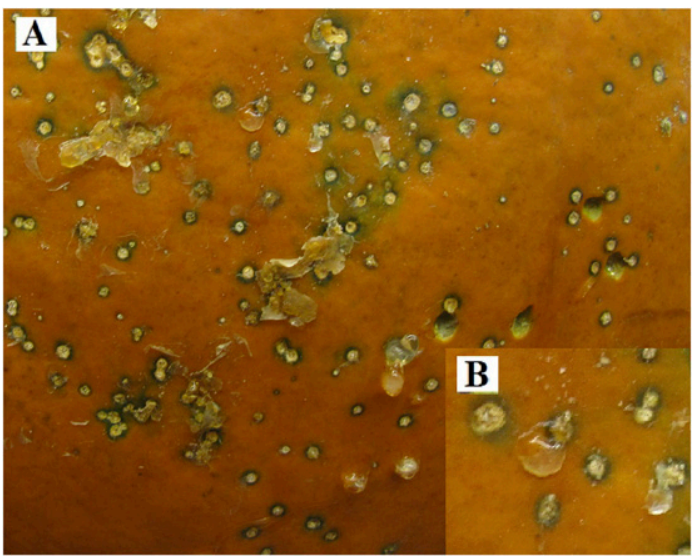

Fig. 4. Ripen pumpkin fruit infected with Xanthomonas cucurbitae. (A) Water-soaked lesions on a ripe pumpkin fruit (cultivar Magic Lantern) and (B) magnified $(5 \times)$ lesions on a ripe pumpkin fruit. using the method reported by Pruvost et al. (2008). KC medium contained $7 \mathrm{~g}$ yeast extract, $7 \mathrm{~g}$ peptone, $7 \mathrm{~g}$ glucose, $18 \mathrm{~g}$ agar, $20 \mathrm{mg}$ propiconazol, $40 \mathrm{mg}$ cephalexin, and $20 \mathrm{mg}$ kasugamycin in $1000 \mathrm{~mL}$ distilled water (Schaad et al., 2001). Lesions that were different from typical symptoms incited by $X$. cucurbitae were also cultured on nutrient agar and King-B medium (Schaad et al., 2001). The plates were incubated in the dark at $24 \pm 1{ }^{\circ} \mathrm{C}$. After $3 \mathrm{~d}$, xanthomonad-like yellow color colonies were subcultured by streaking onto the Lauria Bertani agar (LB) medium in 100-mm petri plates. After 2 to $3 \mathrm{~d}$, developing colonies were subcultured again on LB medium to prepare single-cell colonies. Three days later, each single-cell colony was transferred into $1.5-\mathrm{mL}$ microcentrifuge tube containing $1 \mathrm{~mL}$ solution of $15 \%$ or $30 \%$ glycerol in SDW, and the tubes were stored at $-20{ }^{\circ} \mathrm{C}$ and $-80{ }^{\circ} \mathrm{C}$, respectively (Goto et al., 1980; Schaad et al., 2001), for future studies.

Identification of X. cucurbitae. Bacterial isolates with xanthomonad-like yellow colonies on $\mathrm{KC}$ medium were tested first for the Gram reaction (Schaad et al., 2001). Gram-negative isolates were streaked onto yeast extract dextrose calcium carbonate agar (YDC) medium (Schaad et al., 2001) in petri plates and incubated in the dark at $28 \pm 1{ }^{\circ} \mathrm{C}$ for $48 \mathrm{~h}$ (Mohammadi et al., 2001; Schaad et al., 2001).

A total of 181 isolates that were identified as $X$. cucurbitae, based on their colony characteristics on KC and YDC (Schaad et al., 2001), were randomly selected for polymerase chain reaction (PCR) test. The primers used were RST2 (5' AGGCCCTGGAAGGTGC CCTGGA 3') and RST3 (5'ATCGCACTGCGTACCGCG CGCGA3 $\left.^{\prime}\right)$. These primers were developed by Leite et al. (1994) for amplifying Xanthomonas spp. PCR test was conducted using a thermal cycler machine (Model PCT-200, MJ Research Inc., Waltham, MA). The $25 \mu \mathrm{L}$ reaction volume contained $12.5 \mu \mathrm{L}$ Go Taq Green Master Mix 2X (Promega Corporation, Madison, WI), $1 \mu \mathrm{L}$ of $10 \mu \mathrm{M}$ of each primers, $10 \mu \mathrm{L}$ of nuclease-free water, and $0.5 \mu \mathrm{L}$ of bacterial suspension $\left[10^{8}\right.$ colony-forming units (cfu)/mL] (Meng et al., 2004; Zhao et al., 2002). The American Type Culture Collection (ATCC) isolate 23378 of $X$. cucurbitae was included as a reference isolate. PCR cycle conditioning included initial denaturation at $95^{\circ} \mathrm{C}$ for $10 \mathrm{~min} ; 32$ cycles of denaturing at $95{ }^{\circ} \mathrm{C}$ for $40 \mathrm{~s}$, annealing at $59{ }^{\circ} \mathrm{C}$ for $40 \mathrm{~s}$, and extension at $72{ }^{\circ} \mathrm{C}$ for $1 \mathrm{~min}$; followed by a final extension step at $72{ }^{\circ} \mathrm{C}$ for $10 \mathrm{~min}$. The PCR product was run in $1 \%$ agarose gel containing ethidium bromide at $100 \mathrm{~V}$ for $60 \mathrm{~min}$, and visualized under ultraviolet light.

Also for further confirmation of the above-tested isolates as Xanthomonas, nucleotide sequences of the 16s rRNA genes were determined. Amplification of 16s rRNA genes was carried out using primers $27 \mathrm{~F}$ (5' AGAGTTTGATCMTGGCTCA G3') and 1492r (5' TACCTTGT TACGACTT3') in the PTC-200 Peltier Thermal cycler (MJ Research Inc., Waltham, MA) (Lane, 1991). PCR cycle 
conditioning was started by initial denaturation at $95{ }^{\circ} \mathrm{C}$ for $10 \mathrm{~min}$, followed by 35 cycles of denaturing at $95{ }^{\circ} \mathrm{C}$ for $40 \mathrm{~s}$, annealing at $58^{\circ} \mathrm{C}$ for $40 \mathrm{~s}$, and extension at $72{ }^{\circ} \mathrm{C}$ for $1 \mathrm{~min}$, followed by a final extension step at $72{ }^{\circ} \mathrm{C}$ for $10 \mathrm{~min}$. The PCR products were purified with the Wizard SV gel and PCR Clean-Up system (Promega). Purified amplicons of 16s rRNA genes were sequenced from both ends ( $5^{\prime}$ forward and $3^{\prime}$ reverse) at the University of Illinois Core DNA Sequencing Facility. Edited sequences were compared using the BLASTn database (http://www.ncbi. nlm.nih.gov).

A total of 67 isolates, considered to be $X$. cucurbitae, were randomly selected for biochemical and physiological tests. Biochemical and physiological tests included urease, catalase, and oxidase reaction, glucose metabolism under aerobic and anaerobic conditions (Hugh and Leifson test), aesculin hydrolysis, starch hydrolysis, $\mathrm{H}_{2} \mathrm{~S}$ production from cysteine, casein degradation, reaction in litmus milk medium, and nitrate reduction (Kado, 2010; Lelliott et al., 1966; Mohammadi et al., 2001; Schaad et al., 2001; Suzuki et al., 2003).

Pathogenicity test of the isolates. In a greenhouse, 134 isolates, considered to be $X$. cucurbitae, were tested for their pathogenicity on pumpkin cultivar Howden, a susceptible pumpkin to $X$. cucurbitae. The isolates were cultured on LB medium in petri plates in the dark at $24 \pm 1{ }^{\circ} \mathrm{C}$. Bacterial inoculum was prepared by washing 2-d-old bacterial colonies with SDW into a beaker. The density of bacterial cells in the suspension was adjusted to $10^{8} \mathrm{cfu} / \mathrm{mL}$ using a spectrophotometer (Smart Spec 3000; Bio-Rad, Philadelphia, $\mathrm{PA})$ at $\mathrm{OD}_{600}(\mathrm{OD}=0.5$ at 600 $\mathrm{nm})$. Plants were inoculated when they were at 2- to 4-leaf growth stages. Using a $10-\mathrm{mL}$ syringe, $0.5 \mathrm{~mL}$ of bacterial suspension was infiltrated into the abaxial side of leaves with five inoculations to each leaf $(0.1 \mathrm{~mL}$ at each inoculating site). ATCC isolate 23378 of $X$. cucurbitae and SDW were used as positive and negative controls, respectively. For each isolate at each time, three plants and three leaves of each plant were inoculated. Inoculated plants were placed in a greenhouse at 24 to $28{ }^{\circ} \mathrm{C}$ with 14 -h photoperiod. During 3 weeks from inoculation, development of the symptoms, including water-soaked and necrotic lesions were recorded. The pathogen was isolated from the symptomatic tissues and identified as previously described (Barak et al., 2001; Schaad et al., 2001).

\section{Results}

\section{Disease development on leaf and fruit}

Leaf symptoms. The earliest plant growth stage that bacterial lesions were observed on true leaves was at the 4-leaf growth stage (Table 3). After that, bacterial lesions on leaves were observed as long as leaf tissues were green (Tables 1-3). Several types of lesions were observed on leaves, which were different in size and color. Three types of lesions were the most common, which were described as Type I, Type II, and Type III lesions (Table 4).

Type I lesion was the most common (Table 4$)$. The lesions were small $(\approx 1 \mathrm{~mm}$ in diameter), angular, water-soaked, and brown. The lesions gradually became necrotic with a chlorotic halo (Fig. 3A). Some lesions enlarged, reaching up to $6 \mathrm{~mm}$ in diameter. In a majority of the infected plants, the lesions coalesced and covered most of the leaf surface. The density of the lesions at the edges of the leaves was usually greater and, after coalescing, caused leaf scorch, which resulted in partial or complete death of the leaf. This type of lesion was observed in most of the pumpkin cultivars such as Champion, Dickinson, Gold Challenger, Gold Strike, Howden, Magic Lantern, Magic Wand, Pie Pumpkin, Progress, and Super Hero (Table 4). The color of the lesions varied from light to dark brown, depending on the pumpkin cultivar. In some cultivars, the center of the lesion fell off, resulting in a shot-hole appearance. Bacterial streaming was easily observed in the leaf sections examined using light microscopy.

Type II lesion was angular, water-soaked, with a grayish center and brown halo (Fig. $3 \mathrm{~B}$ ). In the beginning, lesions were small ( 1 to $2 \mathrm{~mm}$ in diameter), but gradually enlarged reaching up to $4 \mathrm{~mm}$ in diameter, and the centers became translucent. Type II lesions were larger than Type I lesions. This type of lesion was observed on pumpkin cultivars Autumn King, Baby Bear, Baby Boo, and Dill's Atlantic Giant (Table 4). Bacterial streaming was easily observed in the leaf sections examined using light microscopy.

Type III lesion was observed on pumpkin cultivars Dickinson, Iron Man, Pie Pumpkin, and Spartan (Table 4). Lesions were angular, 4 to $8 \mathrm{~mm}$ in diameter and translucent in center with a thin yellow halo (Fig. 3C). There were only a few lesions ( 1 to 10$)$ on each leaf. Bacterial streaming from Type III lesions was slower than that of Type I and Type II lesions in the leaf sections under light microscopic examination.

In the monitored fields, Type I, Type II, and Type III lesions were observed on 10, four, and four cultivars, respectively. Both Type I and Type III lesions were observed on pumpkin cultivars Dickinson and Pie Pumpkin in the same field (Table 4). In unmonitored commercial fields, Type I lesion was also observed on pumpkin cultivars Autumn King, Iron Man, Mustang, and Phantom. Similarly, Type II lesion was observed on pumpkin cultivar Autumn Crown in an unmonitored commercial field.

Fruit symptoms. Bacterial lesions developed on fruit 1 week after fruit set until harvest. In the early stages of fruit development, only a few water-soaked lesions were observed. As fruit grew, numerous and larger bacterial lesions developed on the surface. Size and color of lesions on fruit varied with pumpkin cultivars. Most commonly occurring lesions on immature fruit were small ( $1 \mathrm{~mm}$ in diameter), sunken spot with a beige center and a chlorotic halo (Fig. 3D). The lesions gradually enlarged reaching up to $3 \mathrm{~mm}$ in diameter. The surrounding chlorotic halo of the lesion became dark brown with fruit ripening (Fig. 4). In wet conditions, bacterial ooze was observed on some of the lesions.

Incidence and severity of bacterial spot on leaves. In 2009, lesions on leaves were observed in all of the nine fields monitored. Lesions were observed from 10-leaf growth

Table 1. Incidence and severity of bacterial spot (Xanthomonas cucurbitae) on the leaves and fruit in pumpkin fields in Illinois in 2009.

\begin{tabular}{|c|c|c|c|c|c|c|c|c|}
\hline \multirow[b]{3}{*}{ Field location (county) } & \multicolumn{6}{|c|}{ Bacterial spot on leaves } & & \\
\hline & \multicolumn{2}{|c|}{$\begin{array}{c}\text { Mid-July (10- to 15-leaf } \\
\text { growth stage) }\end{array}$} & \multicolumn{2}{|c|}{$\begin{array}{l}\text { Early August } \\
\text { (fruit set) }\end{array}$} & \multicolumn{2}{|c|}{$\begin{array}{l}\text { Early September } \\
\text { (fruit ripening) }\end{array}$} & \multicolumn{2}{|c|}{ Bacterial spot on fruit ${ }^{z}$} \\
\hline & Incidence $(\%)^{\mathrm{y}}$ & Severity $(\%)^{x}$ & Incidence $(\%)^{\mathrm{y}}$ & Severity $(\%)^{x}$ & Incidence $(\%)^{\mathrm{y}}$ & Severity $(\%)^{x}$ & Incidence $(\%)^{\mathrm{w}}$ & Severity $(\%)^{\mathrm{v}}$ \\
\hline Alpha (Henry) & 61.67 & 2.78 & 61.67 & 11.02 & 78.33 & 11.69 & 75.00 & 4.34 \\
\hline Belleville (St. Clair) & 13.64 & 0.13 & 10.91 & 0.23 & 50.00 & 3.33 & 22.50 & 1.03 \\
\hline Brussels (Calhoun) & 50.00 & 11.68 & 51.18 & 6.00 & 65.83 & 12.10 & 31.76 & 1.45 \\
\hline Champaign (Champaign) & 31.22 & 0.90 & 34.17 & 1.98 & 45.00 & 3.84 & 65.45 & 6.09 \\
\hline Gridley (McLean) & 39.17 & 1.10 & 33.34 & 1.44 & 29.91 & 0.81 & 48.33 & 1.99 \\
\hline Kankakee (Kankakee) & 10.00 & 0.38 & 17.50 & 0.38 & 15.00 & 0.31 & 12.50 & 0.59 \\
\hline Mt. Vernon (Jefferson) & 8.33 & 0.50 & 10.91 & 1.63 & 66.66 & 0.10 & 8.35 & 0.29 \\
\hline Neponset (Putnam) & 58.18 & 1.38 & 63.64 & 11.11 & 68.75 & 6.80 & 96.00 & 9.40 \\
\hline Wayne city (Wayne) & - & - & 65.38 & 8.24 & 68.21 & 12.00 & 95.00 & 13.78 \\
\hline Average & 34.03 & 2.36 & 38.74 & 4.67 & 54.19 & 5.66 & 50.54 & 4.33 \\
\hline
\end{tabular}

${ }^{\mathrm{z}}$ In each field, 60 fruit were examined for presence of symptoms of bacterial spot within 3 weeks of fruit harvest during September and October.

y Percent leaves with bacterial spot. In each visit, 240 leaves in 12 locations ( 20 leaves per location) were examined for development of bacterial spot in each field.

xPercent leaf area with bacterial lesions; the values represent 240 examined leaves in each field.

${ }^{w}$ Percentage of symptomatic fruit over 60 examined fruit.

${ }^{\mathrm{v}}$ Average fruit surface with bacterial spot of 60 fruit. 


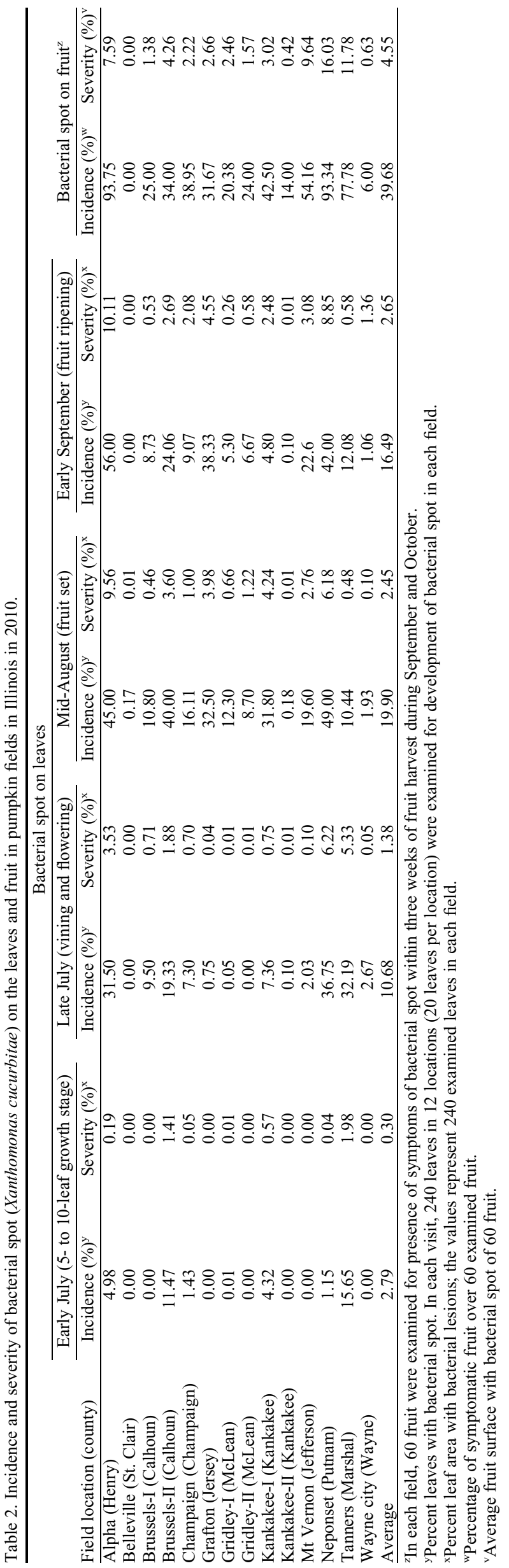

stage (mid-July) until harvest (Table 1). Average incidence of symptomatic leaves in all nine fields monitored was $34.03 \%$, $38.74 \%$, and $54.19 \%$ in the third week of July, second week of August, and first week of September, respectively. Average severity of leaf lesions (percentage of leaf surface with lesions) in all nine fields was $2.36 \%$, $4.67 \%$, and $5.66 \%$, in the third week of July, second week of August, and first week of September, respectively.

In 2010, leaf lesions were observed from 5-leaf growth stage (early July) until harvest in September in all 14 fields monitored. Average incidence of symptomatic leaves in all monitored fields was $2.79 \%, 10.68 \%$, $19.90 \%$, and $16.49 \%$ in the 2 nd week of July, 5th week of July, 2nd week of August, and first week of September, respectively (Table 2 ). Average severity of leaf lesions in the fields was $0.30 \%, 1.38 \%, 2.45 \%$, and $2.65 \%$, in the 2nd week of July, 5th week of July, 2nd week of August, and first week of September, respectively.

In 2011, bacterial lesions on leaves were observed from 4-leaf growth stage (first week of July) until harvest in September in all 15 fields monitored. By the end of July, leaf lesions were observed in all 15 fields. Average incidence of symptomatic leaves in the fields was $6.02 \%, 1.29 \%, 12.08 \%$, and $19.85 \%$ in the first week of July, 3rd week of July, 2nd week of August, and first week of September, respectively (Table 3 ). Average severity of leaf lesions in the fields was $0.24 \%, 0.03 \%, 1.20 \%$, and $2.35 \%$, in the first week of July, 3rd week of July, 2nd week of August, and first week of September, respectively.

Incidence and severity of bacterial spot on fruit at harvest. Bacterial spot was observed on pumpkin fruit in 114 of 132 commercial fields surveyed during 2009-11 (Fig. 2). In 2009, fruit with bacterial lesions were observed in all 17 fields surveyed in 13 counties. Fruit with bacterial spot in the fields ranged from $2 \%$ to $96 \%$ (average $46 \%$ ). Field average severity of lesions on fruit (percent fruit area affected) ranged from $1 \%$ to $14 \%$ (average of all fields $4.0 \%$ ). In 2010, fruit with bacterial lesions were observed in 40 of 50 fields surveyed in 30 counties. Incidence of symptomatic fruit ranged from 3\% to $94 \%$ in the fields with infected fruit. The average incidence of symptomatic fruit in all 50 fields surveyed was $35 \%$. Field average severity of lesions on fruit (average symptomatic areas on 60 fruit) ranged from $1 \%$ to $16 \%$ in the fields with infected fruit. The average severity of the disease in all surveyed fields was $3.1 \%$. In 2011, fruit with bacterial spot was observed in 57 of 65 fields surveyed in 33 counties. Incidence of symptomatic fruit in the fields with the infected fruit ranged from $3 \%$ to $87 \%$. The average incidence of symptomatic fruit in all 65 fields was $24 \%$. Field average severity of lesions on fruit ranged from $1 \%$ to $14 \%$ (average of all surveyed fields $2.2 \%$ ).

Relationship between leaf infection and fruit infection. Overall, correlation 


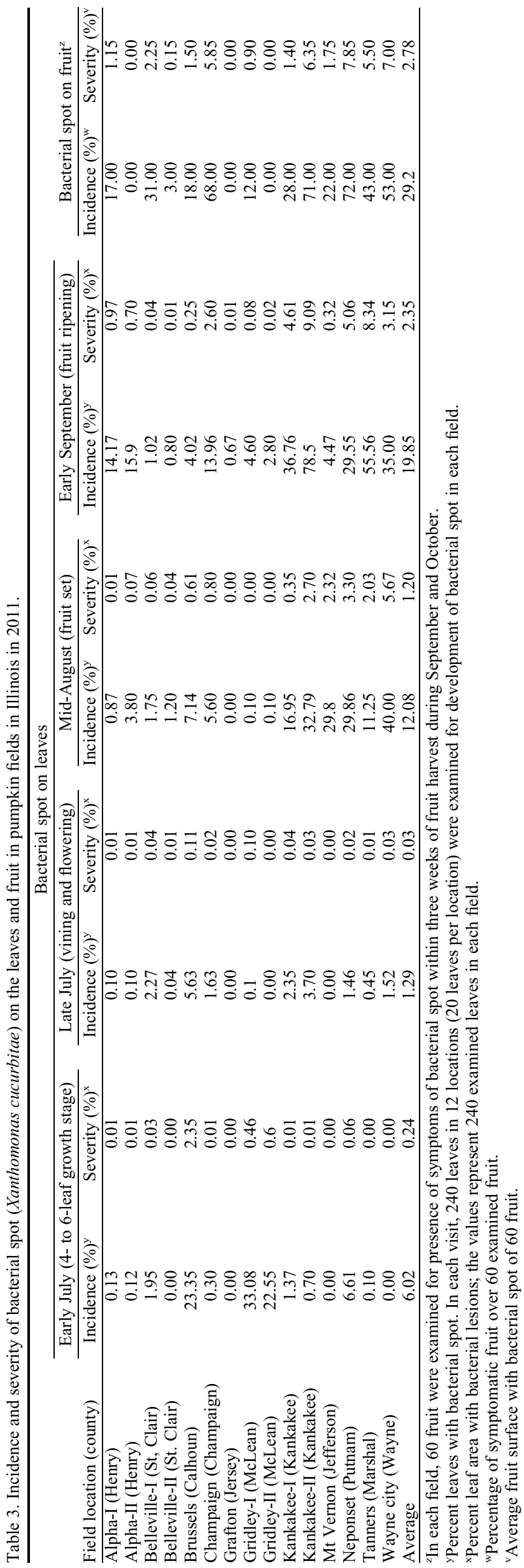

coefficients $\left(R^{2}\right)$ between incidence of bacterial spot at different plant growth stages and fruit at harvest showed that fruit infection was highly correlated with leaf infection at fruit set (Table 5). Combined data from three years showed significant relationship $\left(R^{2}=\right.$ $0.76, P<0.001$ ) between leaf infection at fruit set and fruit infection at harvest. However, correlation between leaf infection at vining growth state and fruit infection at harvest in 2010 was the highest $\left(R^{2}=0.87\right)$.

Isolation of bacteria. During 2009-11, bacteria were isolated from all leaves and fruit with symptoms. A total of 1324 bacterial isolates were collected from 114 pumpkin fields, which included 534 isolates from leaf samples from the monitored fields and 790 isolates from fruit samples from the surveyed fields at harvest. Each isolate was from a single leaf or fruit.

Identification of $X$. cucurbitae isolates. A total of 994 of $1324(75 \%)$ isolates, including 331 and 663 isolates from leaf and fruit, respectively, developed yellow pigmented xanthomonad-like colony on $\mathrm{KC}$ medium and yellow colonies on YDC medium. All 181 of the 994 isolates tested using RST2/3 primers produced amplicons identical to that of the ATCC isolate 23378 of $X$. cucurbitae. The product of PCR with these primers was a $1.4 \mathrm{~kb}$ amplicon (Fig. 5). Thus, 331 (62\%) and $663(84 \%)$ of the bacterial isolates collected from leaf and fruit samples, respectively, were identified as $X$. cucurbitae. Following amplification of the isolates using $27 \mathrm{~F}$ and $1492 \mathrm{r}$ primers, analysis of sequences of $16 \mathrm{~s}$ rRNA genes in all isolates showed $97 \%$ to $99 \%$ similarity with Xanthomonas species (e.g., $X$. campestris) in the National Center for Biotechnology Information (NCBI) data bank.

Biochemical and physiological tests showed that all 67 isolates were Gram negative, urease negative, oxidative positive, fermentative negative, hydrolyzed aesculin and starch, produced levan from sucrose, grew on semiselective xanthomonad agar (SX) medium, produced $\mathrm{H}_{2} \mathrm{~S}$ from cysteine, and reduced nitrate. All of the tested isolates hydrolyzed casein in skim milk and the reactions were alkaline.

Pathogenicity test of the isolates. All 134 tested isolates for their pathogenicity produced lesions on true leaves of pumpkin cultivar Howden after 1 week. Developed lesions were similar to the Type I lesion described from the field studies. Lesion similar to the Type I lesion were produced in the plants inoculated with ATCC isolate 23378. No lesion was produced in the plants injected with SDW. Reisolated bacteria from the inoculated plants produced yellow colonies on YDC medium and $1.4 \mathrm{~kb}$ amplicon with RST2/3 primers in the PCR tests. Thus, the reisolated bacteria were identified as $X$. cucurbitae.

\section{Discussion}

The results of this study showed that bacterial spot incited by X. cucurbitae occurs 
widely in pumpkin fields in Illinois. Similar reports have been published on the occurrence of bacterial spot in some pumpkin growing areas in eastern United States, from Rocky Mountains to the Pacific Coast (Babadoost et al., 2012; Dutta et al., 2013; Williams and Zitter, 1996) and other pumpkin-growing areas of the World (Lamichhane et al., 2010; Pruvost et al., 2008; Williams and Zitter, 1996). Bacterial spot also occurs widely on gourds and winter squash in Illinois (unpublished data). Since only little is known about bacterial spot, comprehensive studies on the etiology of this disease in all cucurbit crops are needed for development of effective strategies for its management.

Our study showed that bacterial spot on pumpkin leaves develop from the early growth stage (4-leaf stage) until harvest of the crop. The results also showed that pumpkin

Table 4. Lesion types developed on pumpkin leaves infected with Xanthomonas cucurbitae in Illinois during 2009-11.

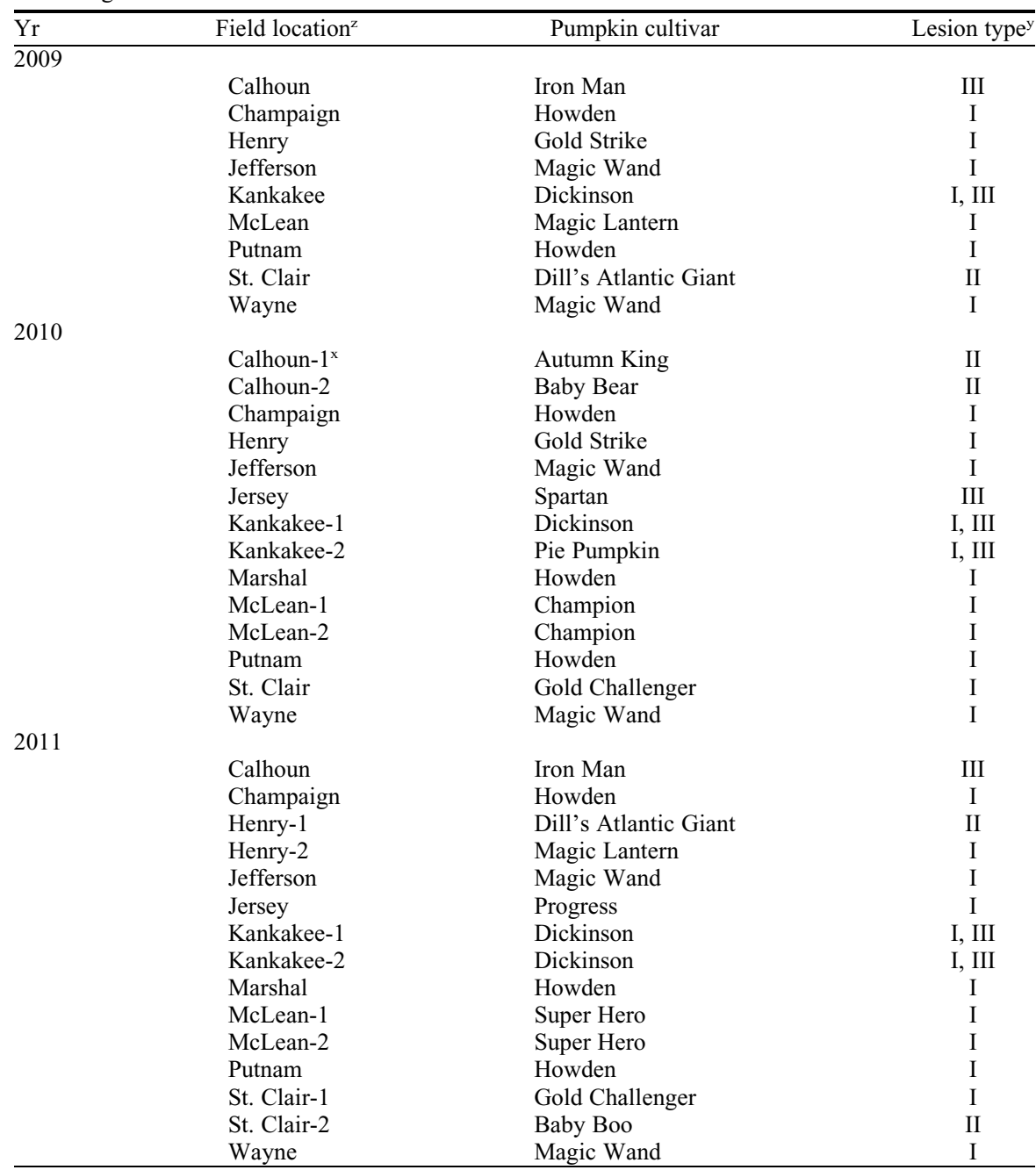

${ }^{2}$ County where the filed located.

${ }^{y}$ Three types of lesions (Type I, Type II, Type III) observed. Characteristics of the lesions are described in the text.

${ }^{x}$ Number indicate number of fields monitored in the same county. fruit can be infected by $X$. cucurbitae from early fruit development until harvest. Thus, management strategies of bacterial spot in pumpkin fields should aim at season-long protection of both leaves and fruit. However, the effects of environmental conditions (e.g., moisture and temperature) on development and spread of bacterial spot on leaves and fruit of pumpkins were not investigated in this study. So, further studies on the epidemiology of bacterial spot in pumpkin and other cucurbits are needed.

Symptoms of bacterial spot on cucurbit leaves have been described by other investigators (Blancard et al., 1994; Bryan, 1930; Koike et al., 2007; Williams and Zitter, 1996). This study, however, was a comprehensive investigation on development of bacterial spot on various pumpkin cultivars, which resulted in defining two new leaf lesions (Type II and Type III lesions) on pumpkins. Thus, the findings of this study are expected to help in accurate diagnosis of the disease and effective management of $X$. cucurbitae.

In most of the pumpkin cultivars monitored, only one type of lesion was observed. In some cultivars (e.g., Dickinson and Pie Pumpkin), however, two types of lesions were observed. This observation may be related to: 1) growing mixed cultivars (e.g., 'Dickinson' and 'Pie Pumpkin') by producers and 2) development of lesion type is affected by the environmental conditions in different areas. Additional studies could clarify symptom development of bacterial spot on cucurbit cultivars in different areas and under different environmental conditions.

Leaf infection with $X$. cucurbitae does not result in leaf or plant death of pumpkins. Infected leaves, however, are likely providing inoculum for fruit infection, as leaf infection occurs before fruit development Thus, control of leaf infection by $X$. cucurbitae may prevent or reduce fruit infection. Based on the correlation coefficients between leaf infection and fruit infection, it appears that leaf infection at the growth stages of vining and fruit set result in higher incidence of fruit infection.

In pumpkin, fruit infection with $X$. cucurbitae is important because: 1) infected fruit results in yield losses in the field (Babadoost and Ravanlou, 2012), and 2) infection of fruit by $X$. cucurbitae provides opportunities for fruit colonization by other organisms, such as

Table 5. Correlation coefficient $\left(R^{2}\right)$ between incidence of bacterial spot on leaves at different plant growth stages and fruit at harvest in pumpkin fields in Illinois during 2009-11.

\begin{tabular}{|c|c|c|c|c|c|}
\hline \multicolumn{6}{|c|}{ Correlation coefficient $\left(R^{2}\right)^{z}$} \\
\hline \multicolumn{2}{|c|}{2009} & \multicolumn{2}{|c|}{2010} & \multicolumn{2}{|c|}{2011} \\
\hline Bacteria spot on leaves $^{y}$ & Bacterial spot on fruit ${ }^{\mathrm{x}}$ & Bacteria spot on leaves $^{y}$ & Bacterial spot on fruit ${ }^{\mathrm{x}}$ & Bacteria spot on leaves $^{y}$ & Bacterial spot on fruit ${ }^{\mathrm{x}}$ \\
\hline 10- to 15 -leaf growth & & & & & \\
\hline - & - & Vining and flowering & 0.87 & Vining and flowering & 0.42 \\
\hline Fruit set & 0.87 & Fruit set & 0.72 & Fruit set & 0.66 \\
\hline Fruit ripening & 0.47 & Fruit ripening & 0.76 & Fruit ripening & 0.51 \\
\hline
\end{tabular}

${ }^{\mathrm{z}}$ Leaf and fruit infections were monitored in 9, 14, and 15 fields in 2009, 2010, and 2011 commercial fields, respectively.

yercent leaves with bacterial spot. In each visit, 240 leaves in 12 locations (20 leaves per location) were examined for development of bacterial spot in each field.

${ }^{x}$ In each field, 60 fruit were examined for presence of symptoms of bacterial spot within three weeks of fruit harvest during September and October. 


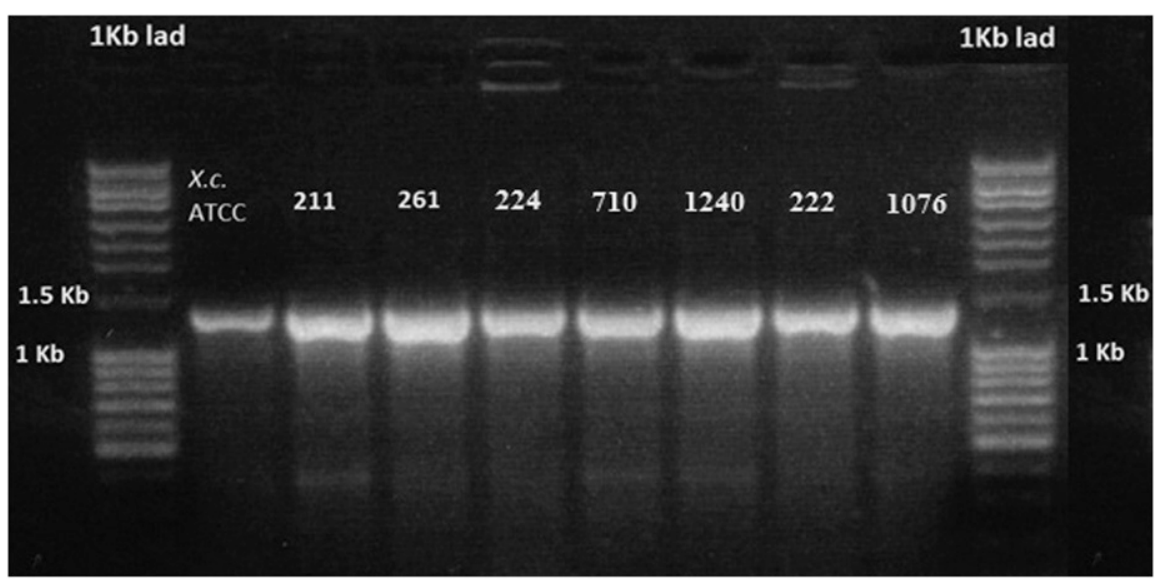

Fig. 5. Polymerase chain reaction product of Xanthomonas cucurbitae following amplification with primers RST2 (5' AGGCCCTGGA AGGTGCCCTGGA3') and RST3 (5'ATCGCACTGCGTACCGCGC GCGA3'). Produced amplicon was $1.4 \mathrm{~kb}$ with all of the isolates tested.

Fusarium and Erwinia species (Babadoost and Zitter, 2009; Saddler and Bradbury, 2005; Winkler et al., 2008), which results in rapid fruit rot. As few as a single lesion of bacterial spot on a pumpkin fruit may result in rotting of the fruit, either in the field or later in storage. Therefore, pumpkin fruit with bacterial spot is usually rejected for marketing. Thus, growers consider almost a zero tolerance of bacterial spot on pumpkin fruit.

RST2/3 primers have been widely used to identify Xanthomons spp. from other bacteria (Dutta et al., 2013; Pruvost et al., 2008; Schaad et al., 2001). These primers produce 1400 bp amplicon with $X$. cucurbitae, while the amplicons produced by other Xanthomonas spp. with these primers are $840 \mathrm{bp}$. Thus, by using RST $2 / 3$ primers not only $X$. cucurbitae is differentiated from nonXanthomonas bacteria, but also it is identified from other Xanthomonas spp.

In this study, several primers were tested for identification of $X$. cucurbitae. Primer pairs RST2/RST3 produced consistent amplicons with $X$. cucurbitae when they were used with pure cultures of $X$. cucurbitae. However, using the primers for detection of $X$. cucurbitae in infected leaf or fruit was unsuccessful. The possible reason for this failure could be presence of PCR inhibitors in the plant extract.

\section{Literature Cited}

Babadoost, M. and A. Ravanlou. 2012. Outbreak of bacterial spot (Xanthomonas cucurbitae) in pumpkin fields in Illinois. Plant Dis. 96:1222.

Babadoost, M., A. Ravanlou, D.S. Egel, and D. O'Brien. 2012. Occurrence of bacterial spot
(Xanthomonas cucurbitae) in pumpkin fields in the Midwest. Phytopathology 102:S4.8.

Babadoost, M. and S.Z. Islam. 2003. Fungicide seed treatment effects on seedling damping-off of pumpkin caused by Phytophthora capsici. Plant Dis. 87:63-68.

Babadoost, M. and T.A. Zitter. 2009. Fruit rots of pumpkin: A serious threat to the pumpkin industry. Plant Dis. 93:772-782.

Barak, J.D., S.T. Koike, and R.L. Gilbertson. 2001. The role of crop debris and weeds in the epidemiology of bacterial leaf spot of lettuce in California. Plant Dis. 85:169-178.

Bineeta, S.B., S. Majumder, and S. Kumar. 1999. Fungal and bacterial diseases of cucurbits, $\mathrm{p}$. 251-252. In: L.R. Verma and R.C. Sharma (eds.). Diseases of horticultural crops: Vegetables, ornamentals and mushrooms. Indus Publishing, New Delhi, India.

Blancard, D., H. Lecoq, and M. Pitrat. 1994. A color atlas of Cucurbit disease: Observation, identification, and control. John Wiley \& Sons, New York, NY.

Bryan, M.K. 1930. Bacterial spot of squash. J. Agr. Res. 40:385-391.

Dutta, B., R.D. Gitaitis, K.J. Lewis, and D.B. Langston. 2013. A new report of Xanthomonas cucurbitae causing bacterial leaf spot of watermelon in Georgia, USA. Plant Dis. 97:556.

Goto, M., T. Takahashi, and M.A. Messina. 1980 A comparative study of the isolates of Xanthomonas campestris pv. citri isolated from citrus canker in Japan and cancrosis B in Argentina. Ann. Phytopathol. Soc. Jpn. 46:329-338.

Kado, C.I. 2010. Rapid necrotizing diseases, p. 79-84. In: C.I. Kado (ed.). Plant bacteriology. American Phytopathological Society, St. Paul, MN.

Koike, S.T., P. Gladders, and A.O. Paulus. 2007. Vegetable diseases, a color handbook. Academic Press, Boston, MA.

Lamichhane, J.R., L. Varvaro, and G.M. Balestra. 2010. Bacterial leaf spot caused by Xanthomonas cucurbitae reported on pumpkin in Nepal. New Disease Reports 22:20.
Lane, D.J. 1991. 16S/23S rRNA sequencing, p. 115-175. In: E. Stackebrandt and M. Goodfellow (eds.). Nucleic acid techniques in bacterial systematics. John Wiley \& Sons, Chichester, UK.

Leite, R.P., Jr., G.V. Minsavage, U. Bonas, and R.E. Stall. 1994. Detection and identification of phytopathogenic Xanthomonas strains by amplification of DNA sequences related to the hrp genes of Xanthomonas campestris pv. vesicatoria. Appl. Environ. Microbiol. 60:1068-1077.

Lelliott, R.A., E. Billing, and A.C. Hayward. 1966. A determinative scheme for the fluorescent plant pathogenic pseudomonads. J. Appl. Bacteriol. 29:470-489.

Meng, X.Q., K.C. Umesh, R.M. Davis, and R.L. Gilbertson. 2004. Development of PCR-based assays for detecting Xanthomonas campestris pv. carotae, the carrot bacterial leaf blight pathogen, from different substrates. Plant Dis. 88:1226-1234.

Mohammadi, M., M-R. Mirzaee, and H. Rahimian. 2001. Physiological and biochemical characteristics of Iranian isolates of Xanthomonas axonopodis pv. citri, the causal agent of citrus bacterial canker disease. J. Phytopathol. 149:65-75.

Pruvost, O., I. Robene-Soustrade, N. Ah-You, E. Jouen, C. Boyer, F. Waller, and B. Hostachy. 2008. First report of Xanthomonas cucurbitae causing bacterial leaf spot of pumpkin on Reunion Island. Plant Dis. 92:1591.

Pruvost, O., I. Robène-Soustrade, N. Ah-You, E. Jouen, C. Boyer, G. Wuster, B. Hostachy, C. Napoles, and W. Dogley. 2009. First report of Xanthomonas cucurbitae causing bacterial leaf spot of watermelon in the Seychelles. Plant Dis. 93:671.

Saddler, G.S. and J.F. Bradbury. 2005. Xanthomonadales, p. 63-121. In: D.J. Brenner, N.R. Krieg, J.T. Staley, and G.M. Garrity (eds.). Bergey's manual of systematic bacteriology. 2nd ed. Springer, New York, NY.

Schaad, N.W., B.J. Jones, and W. Chun (eds.). 2001. Laboratory guide for identification of plant pathogenic bacteria. 3rd ed. American Phytopathological Society, St. Paul, MN.

Suzuki, A., M. Togawa, K. Ohta, and Y. Takikawa. 2003. Occurrence of white top of pea caused by a new isolate of Pseudomonas syringae pv. pisi. Plant Dis. 87:1404-1410.

Vauterin, L., B. Hoste, K. Kersters, and J. Swings. 1995. Reclassification of Xanthomonas. Intl. J. of Systematic Bacteriology 45:472-489.

Williams, P.H. and T.A. Zitter. 1996. Bacterial leaf spot, p. 35. In: T.A. Zitter, D.L. Hopkins, and C.E. Thomas (eds.). Compendium of cucurbit diseases. American Phytopathological Society, St. Paul, MN.

Winkler, J., B. Freistetter, and H. Huss. 2008. The effect of different varieties on fruit rot incidence during ripening of oilseed pumpkin (Cucurbita pepo var. styriaca). Saatgut Osterreichs 59:137-138.

Zhao, Y.F., J.P. Damicone, and C.L. Bender. 2002. Detection, survival, and sources of inoculums for bacterial diseases of leafy crucifers in Oklahoma. Plant Dis. 86:883-888. 